\title{
EDITORIAL NOTES AND ANNOUNCEMENTS
}

(C) The Ichthyological Society of Japan 2015

\section{New Editor-in-Chief}

Please note that effective 1 January 2016, Dr. Yoshiaki Kai succeeded Dr. Hisashi Imamura as Editor-in-Chief of Ichthyological Research.

\section{New Managing Editor}

Please note that effective 1 January 2016, Dr. Naoki Yagishita succeeded Dr. Yoshiaki Kai as Managing Editor of Ichthyological Research. 